\title{
Tutkimusta ryhmissä - dynamiikkaa ja pelisääntöjä
}

Lena M. Levander, Viikin opetuksen kehittämispalvelut, Helsingin yliopisto, PL 62 (Viikinkaari11), 00014 Helsingin yliopisto,lena.levander@helsinki.fi

\section{Johdanto}

Ihmisten toimintatapoihin on jo aikojen alusta kuulunut toimiminen ryhmissä. Ryhmä tuo turvallisuutta ja johonkin kuulumisen tunnetta. Ihminen myös oppii yhdessä ja toisilta. Lisäksi ryhmä, joka on valmis työskentelemään yhteisen hyvän puolesta, selviää paremmin kuin yksinäiset tai ne ryhmän jäsenet, jotka ajattelevat vain omaa etuaan (Goleman 1999). Myös tieteellisten kysymysten ratkaisussa tarvitaan usein eri henkilöiden ajattelutyötä ja moni keksintö on kehittynyt useamman henkilön työpanoksena. Kalevi Rantasen mukaan (2003) tutkimus on osoittanut, että uudet ideat eivät synny yksinäisten aivojen työskentelyn tuloksena, vaan ihmisten välisen vuorovaikutuksen inspiroimana. Työelämässä ei selviä ilman muiden tietoja ja taitoja, koska tarvittavasta osaamisesta vain hyvin pieni osa on yhdellä ihmisellä (Goleman 1999).

Monissa työelämän organisaatioissa tehdään työtä ryhmissä, joita kutsutaan tiimeiksi. Usein kysytään, onko ryhmällä ja tiimillä jotain eroa. Tiimi -sanaa ryhmästä käytetään silloin, kun halutaan korostaa, että ryhmä on koottu harkiten jotain tiettyä tehtävää varten ja sen jäsenet on valittu jonkun erityisosaamisen perusteella (joko sisällöllinen tai toimintatapaan liittyvä). Tiimin toiminnan periaatteisiin kuuluu myös jäsenten välinen tasa-arvoisuus (Belbin 1993). Ryhmäilmiöitä on tutkittu paljon juuri työelämän ryhmissä ja tiimeissä. Ryhmän toimintatapojen tarkoituksenmukaisuuteen ja niiden kehittymiseen tulee kiinnittää huomiota, koska ryhmän työn onnistuminen ei ole itsestään selvää. Ryhmässä ei tehdä vain tehtävää, vaan inhimillinen vuorovaikutus ja siihen liittyvät prosessit ovat aina läsnä.

Tutkimusryhmässä työskentely voi olla innostavaa, mutta myös haastavaa. Miten ryhmän positiivinen voimavara saadaan palvelemaan ryhmän tavoitteita? Toisaalta on inspiroivaa ratkoa itselle kiinnostavia tutkimuskysymyksiä saman alan asiantuntijoiden kanssa. Toisaalta työhön voi liittyä kilpailua, kateutta ja jopa salailua, koska voidaan pelätä sitä, että joku muu hyötyy omista tutkimustuloksista. Tutkijoiden välillä on statuseroja, jotka voivat mahdollistaa toisten jäsenten hyväksikäyttöä. Kenellä on oikeus tutkimustuloksiin, entä mikä nimijärjestys tulee julkaisuun? Inhimilliseen vuorovaikutukseen kuuluvat myös kiintymys- ja vihasuhteet. Näistä selvitään, mikäli ryhmän jäsenillä on sosiaalista älykkyyttä, jota voidaan kutsua myös tunneälyksi. Tunneäly näkyy esimerkiksi ihmisen tavassa osoittaa ymmärrystä toisia kohtaan ja ottaa muiden näkökulmia huomioon. Myös omien impulssien hillitseminen, innostus ja optimismi ovat osa tunneälyä (Goleman 1999). Substanssiosaamisen ja tunneälyn lisäksi ryhmässä tarvitaan yhteisesti sovittuja pelisääntöjä ja toimintatapoja. Voisi olettaa, että akateemisissa työpaikoissa korkeasti koulutetut ihmiset osaavat toimia ryhmässä älykkäästi. Entä jos tunneäly ei ole kehittynyttä? Entä jos ryhmä ei halua kehittää vuorovaikutuksensa laatua tai ryhmän jäsenet eivät pysty olemaan joustavia toimintatavoissaan?

Goleman (1999) kuvailee eräässä yliopistossa tehtyä tutkimusta, jossa koehenkilöistä kerättiin 120 johtoryhmää. Näiden ryhmien piti tehdä päätöksiä kuvitteellista yritystä varten. Joidenkin ryhmien jäsenet olivat älykkyysosamäärältään huippuälykkäitä, mutta ryhmät eivät välttämättä selvinneet tehtävästä kunnialla. Miksi huippuälykkäistä kootut ryhmät eivät pärjänneet? Siksi, että he käyttivät aikaa keskinäiseen kiistelyyn! Jäsenten toimintatapa oli liian samanlainen eli he erittelivät ongelmien älyllisesti haastavia ulottuvuuksia, analysoivat ja arvostelivat. Ryhmässä ei huolehdittu työn suunnittelusta, tiedon kokoamisesta ja muokkaamisesta eikä lopputuloksien levittämisestä. Tulokselliseen yhdessä toimimiseen tarvitaan substanssiosaamisen lisäksi sekä sosiaalista älykkyyttä että yhteistä tehtävien organisoimista.

\section{Inhimillinen vuorovaikutus ryhmässä}

Ihmiset vaikuttavat toisiinsa aina halusivat tai eivät. Parhaimmassa tapauksessa se on aitoa ja tasapuolista "vuorotellen vaikuttamista". Jokaisella yksilöllä on ryhmässä oma dynaaminen kenttänsä ja oma tulkinta tilanteestaan (Kurt Lewin 1935; 1951). Kukin ryhmän jäsen tuo ryhmään mukanaan oman menneisyytensä ja entiset vuorovaikutuskokemuksensa, joiden mukaan hän suuntautuu uuteen ryhmätilanteeseen. Yksilön toiminta on tilanteen dynaamista tulkintaa ja merkityksen antamista. Vuorovaikutuksessa ihmiset eivät reagoi tekoihin, vaan niiden tulkittuun merkitykseen (Jauhiainen ja Eskola 1993). Tämä tarkoittaa esimerkiksi sitä, että keskustelukumppanin sanavalinta, painotukset tai äänensävyt voivat saada kuulijan mielessä sanallisesta viestistä poikkeavan merkityksen. 
Ihmisten välinen vuorovaikutus on joko näkyvää - puhetta, ilmeitä, eleitä - tai näkymätöntä ajatuksia, ennakkokäsityksiä, luuloja ja tulkintoja. Vuorovaikutus ihmisten välillä on tilannesidonnaista, ennakoimatonta ja muuttuu koko ajan. Ryhmän sisäisiä tapahtumia kutsutaan ryhmätilanteen dynamiikaksi. Ihmisten välille syntyy näkymätön ajatusten, mielikuvien, tunteiden ja havaintojen dynaaminen kenttä (Jauhiainen ja Eskola 1993). Kun arkipuheessa käytetään sanaa "henkilökemia" olemme tekemisissä tämän näkymättömän maailman kanssa, jossa eri persoonallisuudet kohtaavat toisensa tunnetasolla. Henkilökemia -käsitteelle ei kuitenkaan ole tieteellisesti määriteltyä sisältöä (Dunderfelt 1998).

Kurt Lewinin tutkimusten (1935) mukaan ihmisen toiminta ryhmässä muodostuu persoonallisuuden ja ympäristötekijöiden yhteisvaikutuksesta. Ryhmän dynamiikkaan vaikuttavat siis myös ulkopuoliset taustatekijät sekä suorituspaineet eikä vain yksilöistä tulevat sisäiset tekijät. Näin ollen ryhmässä syntyvä vuorovaikutus on monen eri tekijän yhteisvaikusta. Käsite "henkilökemia” kuvaa tällöin huonosti ryhmässä syntyvää dynamiikkaa.

\section{Ryhmän dynamiikan elementtejä}

Ryhmän toimintaa eriteltäessä on hyvä muistaa, että ryhmässä lähtee liikkeelle kaksi samanaikaista prosessia: tehtäväkeskeinen toiminta ja tunnekeskeinen toiminta. Ryhmän toiminnalla on siten kaksoistavoite: tehtävään liittyvä asiatavoite ja ryhmän koossa pysymiseen liittyvä tunnetavoite (Jauhiainen ja Eskola 1993). Lisäksi usein käy niin, että ryhmä ei pysähdy pohtimaan, mikä ero on ryhmän tavoitteella ja ryhmän tehtävällä. Ryhmän tehtävä tarkoittaa toiminnan sisältöä ja tavoite kuvaa, mitä tuloksia halutaan saada aikaan. Ryhmällä ei ole tavoitetta ennen kuin se on yhdessä sovittu. Kerran sopiminen ei riitä, vaan tavoitetta tulee aika ajoin tarkistaa. Ryhmän työskentelyn hankaluudet saattavat liittyä myös siihen, että ryhmä aloittaa työn ilman työskentelysuunnitelmaa.

Ryhmien toimintaa analysoitaessa on huomattu, että ryhmä kehittyy ajan kuluessa selvästi havaittavien kehitysvaiheiden kautta, puhutaan ryhmän elinkaaresta eli ajallisesti etenevistä vaiheista. Bruce Tuckman jäsensi 1960-luvulla vaiheet seuraavasti: muotoutuminen, ristiriitavaihe, normien luominen ja tehtävän suorittaminen (Tuckman 1965). Myöhemmin hän lisäsi viimeisen vaiheen eli ryhmän hajoaminen. Ryhmän kehittymisen vaihekuvauksia on muitakin (esimerkiksi Johnson ja Johnson 1987; Jaques 2000). Vaiheet eivät välttämättä seuraa toisiaan ennalta arvattavassa järjestyksessä. Vaiheet voidaan kuitenkin tunnistaa, koska kussakin vaiheessa nousee esille kyseessä olevalle vaiheelle tyypillistä vuorovaikutusta.

Aloitusvaiheessa kukin kyselee itseltään joko tiedostetusti tai tiedostamatta: keitä täällä on, miten olen suhteessa muihin, hyväksytäänkö minut ja mikä on minun tehtäväni? Uudessa tilanteessa saattavat vaikuttaa ennakkotiedot ja -luulot. Ensivaikutelman muodostuminen ja tulkinta tilanteesta tapahtuvat nopeasti ja näitä tulkintoja on vaikea purkaa jälkikäteen. Alkuvaiheessa ryhmä kaipaa ohjeita ja johtajuutta. Ristiriita- eli kuohuntavaiheessa mielipiteitä esitetään reippaasti ja ihmisten välille saattaa muodostua kärjekästä keskustelua. Ryhmän johtajaa testataan ja häntä kohtaan saatetaan esittää kritiikkiä. Tässä vaiheessa on tärkeää, että ristiriitaisista mielipiteistä huolimatta käydään keskustelua ja edistetään sekä tehtävän etenemistä että ryhmän kiinteytymistä.

Ryhmät tarvitsevat yhdenmukaistavia käyttäytymissääntöjä eli normeja. Normien luomisella tarkoitetaan yhteistä keskustelua ja sopimista työskentelyyn liittyvistä pelisäännöistä. Usein normit muotoutuvat sattumanvaraisesti ja sanattomasti. Lisäksi jokainen tuo mukanaan aikaisemmista ryhmistään normeja, jotka eivät välttämättä sellaisenaan ja ilman keskustelua sovi uuteen ryhmään. Jos alkuvaiheessa on pystytty luomaan avoin ja tasavertainen työskentelyilmapiiri, ryhmä työskentelee tietoisesti ja tavoitteellisesti. Tällöin myöhemmin tulevat ristiriidat ovat helpommin ratkaistavissa. Ryhmän hajoamiseen, jäsenten poistumiseen tai uusien mukaan tulemiseen liittyy myös aina koko ryhmää koskevia kysymyksiä.

Eräs keskeinen prosessi ryhmän toiminnassa on viestintä. Kuka puhuu kenelle? Kuinka usein? Ketkä puhuvat keskenään? Viestintä voi olla sekä verbaalista että non-verbaalista. Vaikeneminenkin on viestintää. Viestinnän haasteena on se, että viestit tulkitaan aina omien taustojen mukaisesti, jolloin viesti voidaan ymmärtää eri tavalla kuin sen lähettäjä on tarkoittanut. Lisäksi eri ihmiset kokevat samat asiat eri tavalla. Tämän vuoksi on tärkeää, että ymmärrystä tarkistetaan keskustelun kuluessa joko avoimilla kysymyksillä tai säännöllisillä keskustelun yhteenvedoilla.

Tony Dunderfelt on esittänyt (1998) viisi erilaista viestinnän tasoa:

1. sanallinen (puhe, kielenkäyttö)

2. fyysinen viestintä (ilmeet, eleet, liikkuminen, pukeutuminen, kosketus) 
3. tunneviestintä (tunnelmat, ilmapiiri)

4. intuitiivinen viestintä ("aaltopituus")

5. voimien viestinä (mukana vai ei, viha, rakkaus)

Jokainen meistä liikkuu huomaamattaan kaikilla näillä eri tasoilla jokapäiväisissä vuorovaikutustilanteissa, mutta herkkyys havainnoida ryhmän muita jäseniä voi vaihdella. Viestinnän havainnointi- ja tulkintataidot ovat kehittyneet aikojen alusta saakka. Niiden avulla olemme varmistuneet turvallisuudestamme. Nämä taidot ovat edelleen tarpeen ja osa inhimillistä toimintaamme. Ryhmässä tulee näkyviin viestintätaitojen ja havainnointiherkkyyden erilaisuus. Viestintätapojen erilaisuus saattaa liittyä kasvatukseen, kulttuuritaustan erilaisuuteen, ikään, tapoihin ja tottumuksiin. Jos näistä ei puhuta ääneen, eri ihmisten tulkinnat saattavat aiheuttaa ristiriitoja. Haasteenamme on se, että me emme koskaan voi tietää, miltä toinen ajattelee tai miltä hänestä tuntuu. Hyvä uutinen on se, että viestintä- ja havainnointitaitoaan voi harjaannuttaa.

Ryhmän jäsenille muodostuu vuorovaikutuksessa erilaisia rooleja. Meillä on itsellemme tyypillisiä tapoja toimia ryhmätilanteissa, mutta myös tilanne ja sen synnyttämä vuorovaikutus säätelee toimintatapaa. Rooli voi liittyä johonkin tehtävään kuten esimerkiksi johtamiseen, tutkimiseen tai laboratoriotyön tekemiseen. Sosiaalinen eli toiminnallinen rooli on sekä omalla toiminnalla hankittu että toisten odotuksillaan asettama (Belbin 1993). Jäsenten henkilökohtaiset ominaisuudet, kyvyt ja mieltymykset usein ohjaavat tiettyihin samoihin sosiaalisiin rooleihin. Sosiaalisia rooleja ovat esimerkiksi ideoija, organisoija, sovittelija ja niin edelleen. Sosiaaliseen rooliin voi helposti jäädä kiinni, jolloin se voi jopa haitata ryhmän työskentelyä. Sen lisäksi, että ryhmä keskustelee tutkimukseen liittyvistä sisällöllisistä ja menetelmällisistä aiheista, ryhmän tulee arvioida myös toimintatapaansa. Arvioidessaan toimintaansa ryhmän jäsenet pohtivat roolien tarkoituksenmukaisuutta, antavat palautetta toinen toisilleen ja varmistavat, että jokainen ottaa vastuuta toiminnasta ja tavoitteiden saavuttamisesta.

\section{Pelisäännöt}

Useimmat ongelmat työryhmissä voidaan ehkäistä ennalta sovittujen pelisääntöjen avulla. Jos pelisäännöistä ei ole avoimesti keskusteltu, toimitaan olettamusten ja arvailujen perusteella. On tärkeää, että ryhmä on keskustellut tavoitteestaan ja miettinyt välietappeja niiden tarkistamiseksi. Keskustelu tavoitteista ja toimintatapojen tarkoituksenmukaisuudesta on tehtävä säännöllisesti. Aina kun ryhmään tulee uusia jäseniä, on tarpeen kerrata tavoitteet ja toiminnan suunta yhdessä ryhmän kanssa.

Jokaisen ryhmän jäsenen tulee olla vastuussa ryhmän tarkoituksenmukaisesta toiminnasta niin, että huolehditaan sekä tavoitteiden saavuttamisesta että hyvästä työskentelyilmapiiristä. Jokainen voi kehittää omaa toimintatapaansa ja havainnointikykyä. Ryhmän arvioidessa toimintatapojaan kukin voi kertoa omista havainnoistaan. Ryhmäprosessiin liittyviä ongelmia, jotka tulevat ryhmän sisäpuolelta, on vaikea päästä aluksi kiinni. Kuitenkin niiden selvittämättä jättäminen vie paljon ryhmän jäsenten energiaa. Osallistuminen ei ole vain mukana olemista, vaan vastuun kantamista, jakamista ja oman panoksen antamista (Jauhiainen ja Eskola 1993).

Seuraavat asiat tulisi keskustella ryhmässä:

1. Tavoitteet: Yhteisen vision luominen; mitä olemme tekemässä, mitä tuloksia haluamme saada aikaan? Tavoitteita on tarkistettava säännöllisesti ja etenkin kun ryhmään tulee tai siitä poistuu jäseniä.

\section{Tehtävä: Toiminnan konkreettinen sisältö (esim. mitä tutkimme).}

3. Toimintatapa: Mikä on työsuunnitelma, aikataulu ja vastuualueet. Miten huomioidaan ryhmän jäsenten erilainen osaaminen. Kuinka usein ja miten arvioidaan tavoitteen saavuttamista, toimintatapojen tarkoituksenmukaisuutta ja ilmapiiriä. Miten saadaan ja annetaan palautetta.

Tutkimus ryhmässä tuo omat erityispiirteensä ryhmän työskentelyyn. On kiehtovaa olla yhdessä samasta alasta kiinnostuneiden kanssa, ja tutkimusryhmässä on helpompi kartuttaa tieteellisiä meriittejä. Tutkimusryhmän verkostojen kautta saa kansainvälisiä kontakteja, ja pääsee konferensseihin tai työskentelemään jonnekin muualle. Toisaalta on kohdattava tiedemaailman kilpailu sekä meritoitumisessa että jatkorahoituksen haussa. Ryhmässä saattaa olla sellaisiakin, jotka estävät muita menemästä edelleen tai suorastaan varastavat ideoita. Kateus ryhmän sisällä saattaa olla tuhoava voima, mutta sen voi myös kääntää positiiviseksi voimavaraksi. Kilpailu kuuluu myös tutkijan ammattiin ja 
tutkijoiden on oltava eettisesti valveutuneita ja noudatettava hyvää tieteellistä käytäntöä (Tutkimuseettinen neuvottelukunta 2002). Suositeltavaa on myös tehdä kirjallisia sopimuksia tutkijoiden välillä.

Tony Dunderfeltin (1998) mukaan ryhmän vuorovaikutusta haittaavat eräät myytit. Näitä ovat: Onnellisuus - suljen silmät ristiriidoilta Aikuisuus - kaikkien pitäisi toimia aikuisten tavoin Viattomuus - minä en ainakaan tee niin, minä olen hyvä - muut pahoja

Katastrofit - vaikeudet pahenevat, jos niitä lähtee selvittämään Asiantuntija - en voi mitään, koska en ole saanut siihen koulutusta Muuttumattomuus - ihmiset eivät koskaan muutu

Nämä myytit on syytä romuttaa, mikäli haluamme sekä toimivan ryhmän että hyviä tuloksia.

\section{Kirjallisuus}

Belbin, M. 1993. Team Roles at Work. Butterworth-Heineman, Oxford. Dunderfelt, T. 1998. Henkilökemia. Yhteistyö erilaisten ihmisten välillä. WSOY, Juva.

Goleman, D. 1999. Tunneäly työelämässä. Otava, Helsinki.

Jauhiainen, R. \& Eskola, M. 1993. Ryhmäilmiö. WSOY, Juva.

Jacques, D. 2000. Learning in Groups. A handbook for improving group work. 3rd Edition. Kogan Page, London.

Johnson, D. \& Johnson F. 1987. Joining together: Group Theory and Group Skills. 3.painos. Prentice Hall, New Jersey.

Lewin, K. 1935. A Dynamic Theory of Personality. Selected Papers of Kurt Lewin. McGraw-Hill, New York. Lewin, Kurt. 1951. Field Theory in Social Science. Harper, New York.

Pirnes, U. 1994: Kehittyvät tiimit. JTO tutkimuksia -sarja. Tammerpaino, Tampere.

Rantanen, K. 2003. Luovuus kasvaa porukassa. Tiede 7: 30-33.

Tuckman, B. 1965. Developmental Sequences in Small Groups. Psychological Bulletin 63 (6): 484-399.

Tutkimuseettinen neuvottelukunta. 2002. Hyvä tieteellinen käytäntö ja sen loukkausten käsitteleminen. Opetusministeriö, Helsinki. 